\title{
Penguatan Aspek Produksi dalam Rangka Meningkatkan Kemandirian Ukm Batik Kayu
}

\author{
Ramadoni Syahputra1, Kunnu Purwanto ${ }^{2}$, dan Ahdi Kurniawan ${ }^{3}$ \\ 1,2,3 Program Studi Teknik Elektro, Fakultas Teknik, Universitas Muhammadiyah Yogyakarta \\ Jl. Brawijaya, Geblagan, Tamantirto, Bantul, Yogyakarta \\ ramadoni@umy.ac.id \\ DOI: 10.18196/ppm.31.139
}

\begin{abstract}
Abstrak
Pemerintah sangat mendorong pengembangan industri kreatif agar mampu bersaing secara global. Salah satu industri kreatif yang menjadi andalan di kabupaten Bantul propinsi Daerah Istimewa Yogyakarta adalah industri batik kayu. Daerah Istimewa Yogyakarta merupakan salah satu propinsi penghasil batik kayu yang sudah dikenal baik skala nasional maupun internasional. Aspek historis dan geografis menjadi modal penting bagi industri batik kayu Yogyakarta karena memiliki tradisi membatik yang telah berlangsung berabad-abad. Selain itu sebagai salah tujuan wisata utama di Indonesia, Yogyakarta mendapatkan kemudahan dalam pemasaran produknya. Tujuan Program Pengabdian kepada Masyarakat Program Pengembangan Desa Mitra (PPDM) ini adalah membantu UKM batik kayu di kabupaten Bantul Daerah Istimewa Yogyakarta meningkatkan kapasitas produksi, manajemen usaha, dan pemasaran dalam rangka memperkuat industri batik kayu nasional. Mitra industri batik dalam kegiatan PPDM ini adalah UKM Sanggar Punokawan. Permasalahan prioritas UKM tersebut adalah peningkatan produktivitas dengan penambahan alat produksi modern, penggunaan kompor minyak yang masih konvensional, sistem manajemen masih manual berbasis kertas, belum tersedia sistem informasi produk, pemasaran bersifat konvensional, keterampilan SDM, dan aspek kesehatan dan keselamatan kerja (K3). Hasil kegiatan pengabdian kepada masyarakat memberikan nilai tambah pada mitra, yaitu produktivitas yang meningkat dengan pemanfaatan teknologi yang ramah lingkungan.
\end{abstract}

Kata Kunci: industri batik kayu, teknologi ramah lingkungan, kompor batik listrik

\section{Pendahuluan}

Propinsi Daerah Istimewa Yogyakarta (DIY) telah dikenal sebagai propinsi yang memiliki banyak lokasi destinasi wisata. Propinsi DIY sebagai destinasi wisata memiliki tempat-tempat yang dapat dinikmati keindahannya baik wisata alam, budaya,sejarah, seni dan lainnya. Banyak desa yang memiliki ciri khas dan daya tarik masing-masing yang mendukung Daerah Istimewa Yogyakarta sebagai destinasi wisata terkemuka di Indonesia. Desa-desa tersebut yang kemudian dikembangkanmenjadi desa wisata. Ada banyak desa wisata yang ada di Yogyakarta, sSalah satunya adalah Desa Wisata Krebet yang terletak di Dusun Krebet, Desa Sendangsari, Kecamatan Pajangan, Kabupaten Bantul. Ketrampilan masyarakat Dusun Krebet dalam berinovasi dan menghasilkan karya batik dengan media kayu menjadikan desa ini sebagai sentra kerajinan. Kerajinan batik kayu Desa Wisata Krebet menjadi ciri khas desa ini, yang menarik minat para pembeli baik domestik maupun mancanegara. Para wisatawan tertarik untuk mengunjungi Desa Wisata Krebet tidak hanya untuk sekedar membeli kerajinan batik kayu, tetapi juga ingin mengetahui proses pembuatannya, tradisi masyarakatnya, dan juga untuk menikmati suasana desa yang asri di kawasan perbukitan. 
Keberadaan Desa Wisata Krebet dan aktivitas pariwisata secara tidak langsung telah memberikan perubahan sosio-kultural yang berdampak terhadap kehidupan masyarakat setempat. Perubahan sosio-kultural merupakan gejala yang umum terjadi di setiap masyarakat. Desa Wisata Krebet sebagai sentra kerajinan batik kayu telah memberikan lapangan pekerjaan terhadap masyarakat setempat. Pekerjaan utama masyarakat Krebet sebelumnya adalah petani palawija dan peternak. Kehidupan mereka serba terbatas. Setelah menjadi desa wisata, sebagian besar mata pencaharian penduduk dusun Krebet berubah menjadi pelaku industri pariwisata dan pengrajin batik kayu. Dusun Krebet yang dahulunya berupa hutan dan kurang diperhatikan keberadaannya, kini telah berkembang dan dikenal masyarakat luas setelah banyak warga di dusun ini yang menjadi pengrajin dan pelaku pariwisata. Hal ini sesuai dengan penelitian Sutrisna [1] yang menyatakan bahwa perubahan dalam masyarakat pada prinsipnya merupakan suatu proses yang terus menerus, artinya bahwa setiap masyarakat pada kenyataannya akan mengalami perubahan itu. Akan tetapi perubahan antara masyarakat yang satu dengan masyarakat yang lain tidak selalu sama. Ada masyarakat yang mengalaminya lebih cepat bila dibandingkan dengan masyarakat lainnnya. Dusun Krebet termasuk yang mengalami perubahan yang cepat jika dibandingkan desa lain yang memproduksi jenis kerajinan yang sama.

Produk kerajinan batik kayu dari dusun Krebet ini telah mencapai pangsa pasar luar negeri. Negara-negara tetangga seperti Malaysia dan Brunai Darussalam merupakan sasaran produk kerajinan dusun Krebet, selain pasaran domestik. Salah satu UKM yang telah berpengalaman dalam menghasilkan produk batik kayu yang cukup terkenal adalah Sanggar Punokawan. Contoh produk batik kayu dari Sanggar Punokawan ditunjukkan pada Gambar 1.

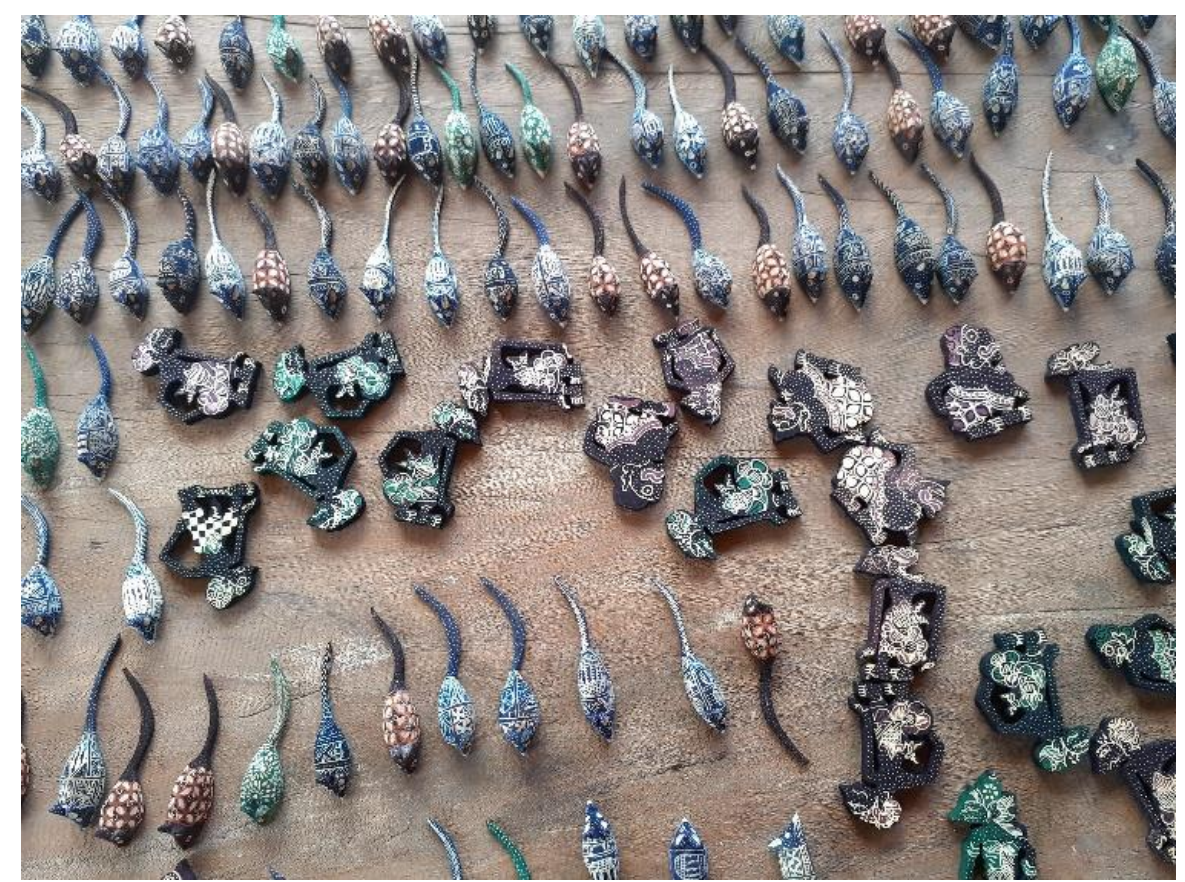




\section{Metode Pelaksanaan}

\section{Pengadaan Kompor Batik Listrik Otomatis untuk Produksi Batik Kayu Serta Pelatihan Penggunaan dan Pemeliharaan}

Pengadaan kompor batik listrik otomatis dan mesin produksi batik kayu berguna untuk menyelesaikan persoalan prioritas mitra pada aspek bisnis produksi dan berdampak pada perbaikan aspek bisnis proses, produk, manajemen, pemasaran, fasilitas, dan finansial.
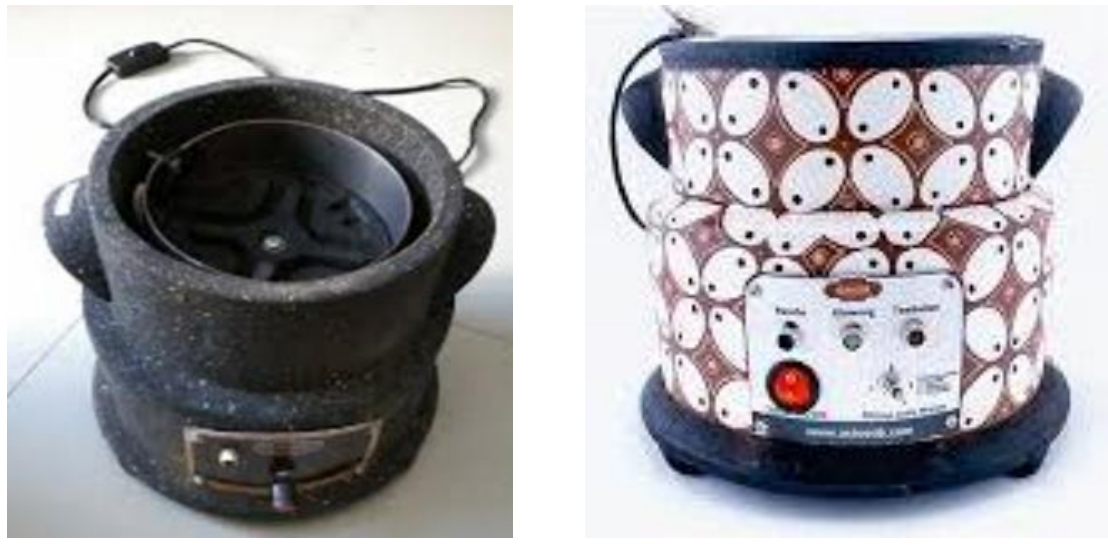

Spesifikasi teknis: Daya: 65 watt, Tegangan: 220 volt, Suhu kerja: $85^{\circ} \mathrm{C}-90^{\circ} \mathrm{C}$ Gambar 2. Kompor Listrik Otomatis Khusus untuk Batik Kayu

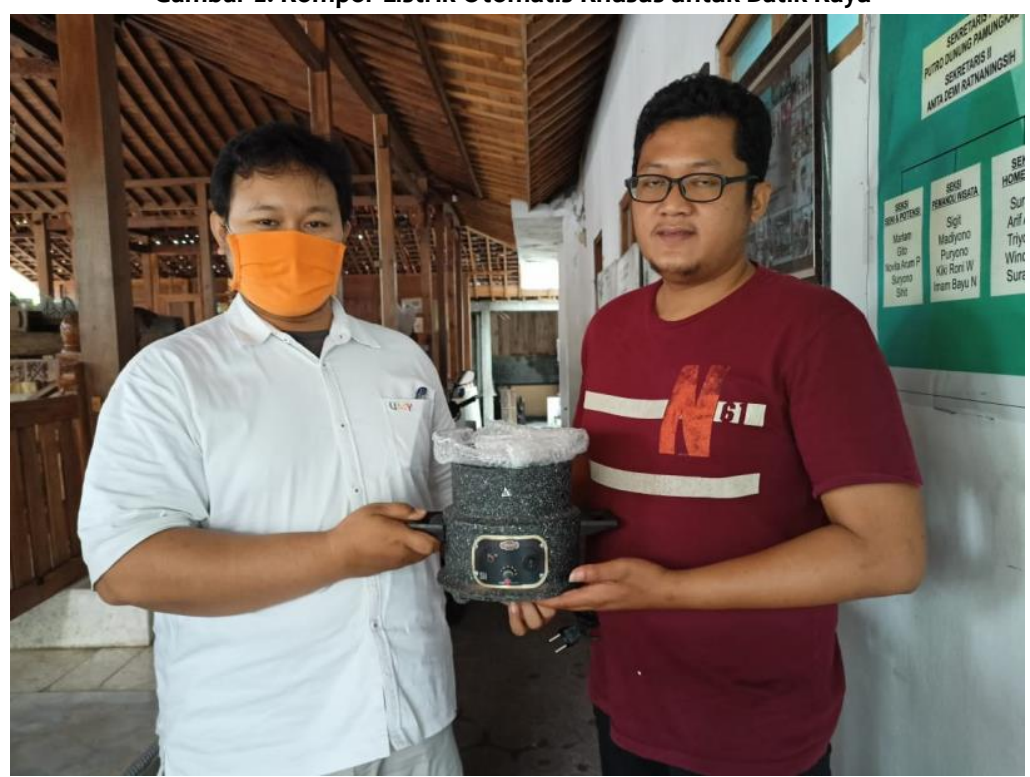

Gambar 3. Serah-Terima Kompor Listrik Otomatis Khusus Untuk Batik Kayu Oleh Tim Pengabdian yang Diaplikasikan Di UKM Sanggar Punokawan, Bantul, DI Yogyakarta

Tersedianya kompor listrik otomatis khusus untuk batik kayu yang diaplikasikan di UKM Sanggar Punokawan, Bantul, DI Yogyakarta, sangat membantu sekali. Kompor batik listrik ini digunakan untuk melukis batik pada hasil kreasi cendera mata dari kayu, di antaranya topeng, alat souvenir gantung, sendok, garpu, mangkuk, dan lain-lain. Kompor batik listrik sangat hemat energi dan hemat biaya. Penggunaan kompor batik listrik mampu menghemat biaya produksi batik kayu hingga 75\% dibandingkan dengan penggunaan kompor minyak tanah. Selain itu, penggunaan kompor listrik juga tidak menyebabkan polusi udara sebagaimana dihasilkan pada penggunaan kompor minyak tanah. 


\section{Pengadaan Mesin Amplas Duduk dan Mesin Bor untuk Produksi Batik Kayu}

Tersedianya mesin amplas duduk dan mesin bor kecil untuk produksi batik kayu, memungkinkan inovasi produk untuk asbak, tempat lilin yang memperluas jangkauan pasar di China dan India. Tersedianya kedua mesin ini memungkinkan inovasi produk untuk gantungan kunci yang diminati oleh buyer dari Singapura.

Faktor pendukung kegiatan ini adalah:

1. Dukungan mitra dalam menjalankan kegiatan baik dukungan material, finansial maupun pikiran.

2. Karyawan dan pemilik yang bersedia menyediakan waktu.

3. Terbukanya mitra kepada pengabdi

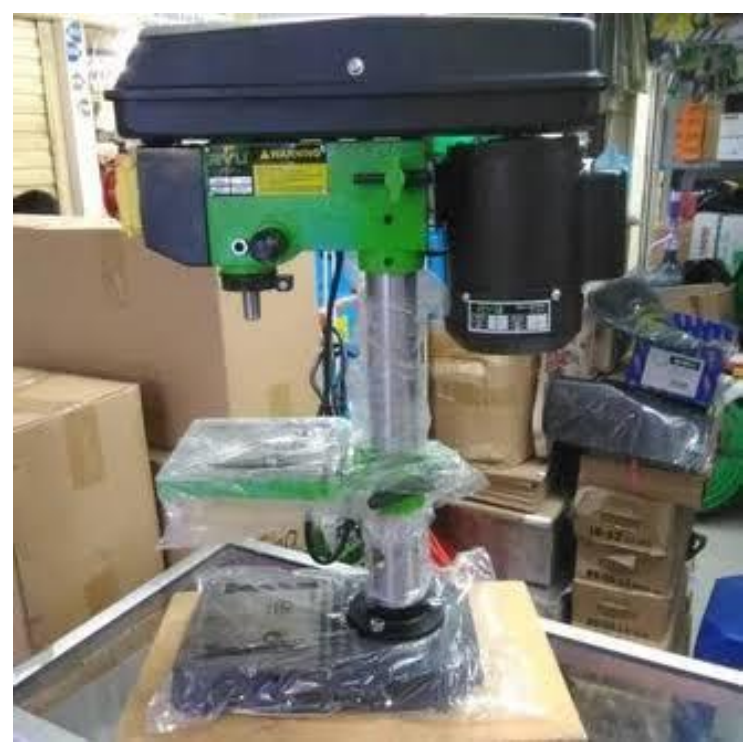

Gambar 4. Mesin Bor

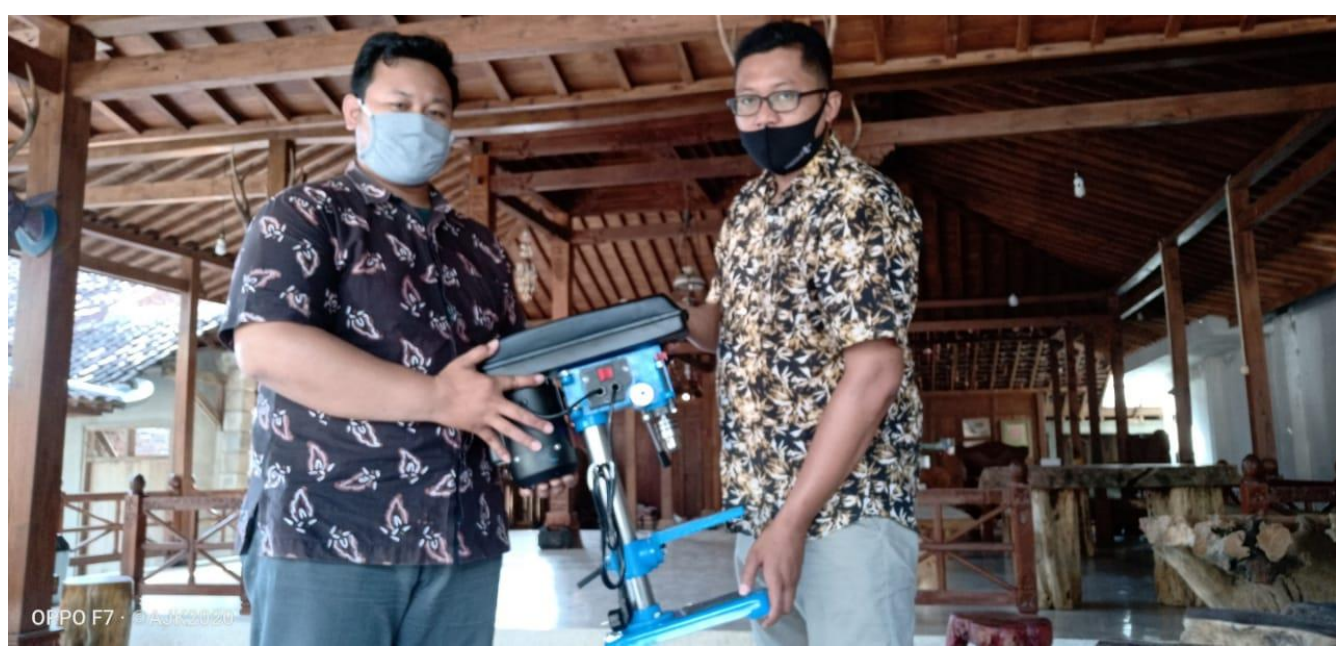

Gambar 5. Serah-Terima Mesin Bor untuk Batik Kayu Oleh Tim Pengabdian yang Diaplikasikan Di UKM Sanggar Punokawan, Bantul, DI Yogyakarta 


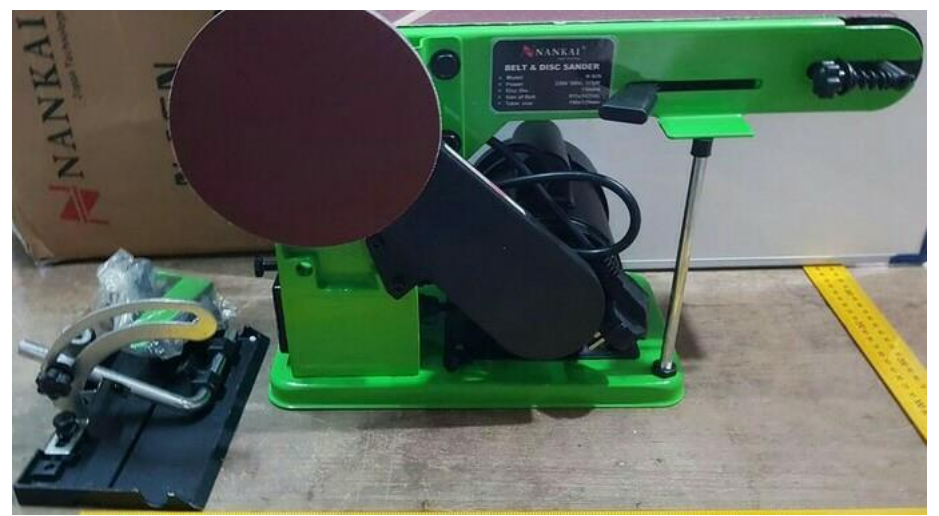

Gambar 6. Mesin Amplas Duduk

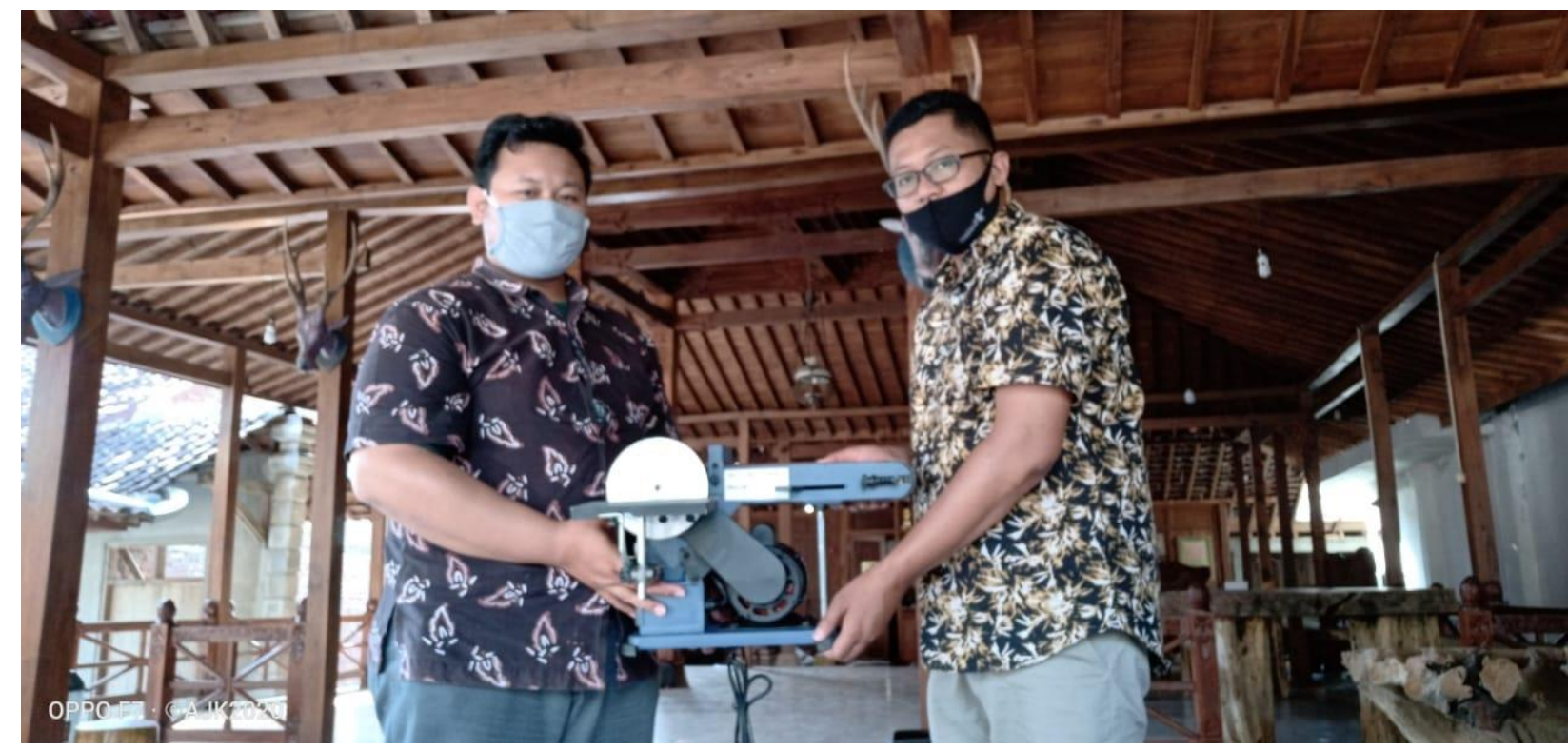

Gambar 7. Serah-Terima Mesin Amplas Duduk untuk Batik Kayu Oleh Tim Pengabdian Yang Diaplikasikan di UKM Sanggar Punokawan, Bantul, DI Yogyakarta

\section{Hasll dan Pembahasan}

Dalam kegiatan pengabdian kepada masyarakat ini, UKM Sanggar Punokawan didorong untuk menggunakan kompor batik listrik dalam proses produksi batik kayu. Kompor listrik yang bekerja pada tegangan $220 \mathrm{~V}$ mengkonsumsi daya maksimum 65 watt terutama pada saat awal memanaskan lilin (malam). Jika lilin sudah mencair pada suhu sekitar $85^{\circ} \mathrm{C}-90^{\circ} \mathrm{C}$ dan siap digunakan untuk membatik, maka daya kompor listrik dapat diturunkan hingga sekitar 60 watt menggunakan potensioner yang terdapat pada kompor batik listrik. Penggunaan kompor listrik ini dapat menggunakan sumber energi listrik PLN maupun sumber energi listrik energi terbarukan misalnya dari solar home system (SHS). Untuk SHS yang menghasilkan arus DC, maka harus dibolak-balikkan menjadi arus AC menggunakan inverter. Baik menggunakan listrik SHS maupun listrik PLN, kompor listrik lebih hemat jika dibandingkan dengan kompor minyak 
tanah maupun kompor gas elpiji. Selain itu, keuntungan menggunakan kompor listrik adalah lebih ramah lingkungan, karena tidak menimbulkan polusi dan lebih aman dari bahaya kebakaran. Sebagai ilustrasi, diuraikan perbandingan biaya bahan bakar berikut ini. Harga-harga komoditas sesuai harga pasaran di Yogyakarya pada bulan Agustus 2020.

a. Kompor batik berbahan bakar minyak tanah

Jumlah kompor $=2$ buah

Konsumsi minyak tanah untuk 1 kompor per hari $(7$ jam $)=1 / 2$ liter

Harga minyak tanah per liter $=\operatorname{Rp} 12.500,-$

Konsumsi minyak tanah untuk 2 kompor per hari adalah:

$=2 \times 1 / 2$ liter/hari $\times$ Rp 12.500,-/liter

$=\operatorname{Rp} 12.500,-/$ hari

Konsumsi minyak tanah untuk 2 kompor per bulan adalah:

$=26$ hari/bulan $\times$ Rp 12.500,-/hari $\quad$ (asumsi: 1 bulan=26 hari kerja)

$=\operatorname{Rp} 325.000,-/$ bulan

Konsumsi minyak tanah untuk 2 kompor per tahun adalah:

$=12$ bulan/tahun x Rp 325.000,-/bulan

$=$ Rp 3.900.000,-/tahun

b. Kompor batik listrik dengan sumber energi listrik PLN

Jumlah kompor $=2$ buah

Daya listrik setiap kompor $=125$ watt

Konsumsi energi listrik 1 kompor per hari (7 jam)

$=125$ watt $\times 7 \mathrm{jam} / \mathrm{hari}=875 \mathrm{Wh} / \mathrm{hari}=0,875 \mathrm{kWh} / \mathrm{hari}$

Biaya pemakaian energi listrik untuk golongan tarif PLN R-1/TR

Konsumsi energi listrik untuk 2 kompor per hari adalah:

$=2 \times 0,875 \mathrm{kWh} / \mathrm{hari} \times \mathrm{Rp} 1.090 / \mathrm{kWh}$

$=\operatorname{Rp} 1.907,5 /$ hari

Konsumsi minyak tanah untuk 2 kompor per bulan adalah:

$=26$ hari/bulan $x \operatorname{Rp~1.907,5/hari~(asumsi:~} 1$ bulan=26 hari kerja)

$=\operatorname{Rp} 49.595,-/$ bulan

Konsumsi minyak tanah untuk 2 kompor per tahun adalah:

$=12$ bulan/tahun $x \operatorname{Rp} 49.595,-/$ bulan

$=$ Rp 595.140,-/tahun 


\section{SImpulan}

Berdasarkan hasil kegiatan pengabdian kepada masyarakat di UKM batik kayu Sanggar Punokawan, dapat disimpulkan bahwa:

1. UKM batik kayu Sanggar Punokawan sangat antusias menerima dan mendukung kegiatan ini, yang dibuktikan dengan benar-benar meningkatkan sarana-prasarana dan kinerja UKM.

2. UKM batik kayu Sanggar Punokawan merasakan manfaat yang besar terhadap adanya kompor batik listrik dan pengadaan peralatan produksi mesin bor dan mesin amplas duduk, karena sangat bermanfaat bagi proses produksi mereka.

3. UKM batik kayu Sanggar Punokawan kepada LP3M UMY karena telah berkenan menerima mereka sebagai mitra kegiatan pengabdian kepada masyarakat ini, sekaligus berterima kasih telah membiayai pelaksanaan kegiatan pengabdian ini.

4. Semoga kerjasama yang baik dan saling menguntungkan ini dapat berkesinambungan.

\section{Ucapan Terlma Kaslh}

Penulis menyampaikan terima kasih yang sebesar-besarnya kepada LP3M UMY yang telah memberikan dukungan penuh dalam pelaksanaan kegiatan pengabdian kepada masyarakat tahun 2020 ini melalui skema PPDM.

\section{Daftar Pustaka}

Bock, J.P., Jason R. Robison, Rajesh Sharma, Jing Zhang, Malay. K. Mazumder, 2008, An Efficient Power Management Approach for Self-Cleaning Solar Panels with Integrated Electrodynamic Screens, Proc. ESA Annual Meeting on Electrostatics 2008.

Cockburn, A. and McKenzie, B. (2009). What Do Web Users Do? An Empirical Analysis of Web Use. International Journal of Human-Computer Studies, 54(6): 903-922.

Hasmiansyah, Yayahya C. A., Suryon, 2012, Rancang Bangun Tenaga Listrik Hybrid Untuk Suplay Beban Pnerangan Umum Type Led, Surabaya.

Kellar, M., Watters, C. and Inkpen, K. M. (2007). An Exploration of Web-Based Monitoring: Implications for Design. In Proceedings of CHI 2007, San Jose,CA, 377- 386.

Smith, N., 2006, Dynamic Power Path Management Simplifies Battery Charging from Solar Panels, Applications Repport, Texas Instruments.

Sutrisna. (2008). Dampak Industrialisasi Terhadap Aspek Sosial Ekonomi Masyarakat Jurnal Industri dan Perkotaan Volume XII Nomor 1769 22/Agustus 2008, pp. 1743 -1752.

nilai-nilai Pancasila 